\title{
Occurrence of Thanatus atratus Simon, 1875 (Araneae: Philodromidae) in Poland
}

\author{
ROBERT ROZWAŁKA ${ }^{1}$; TOMASZ RUTKOWSKI ${ }^{2}$; WOJCIECH STARĘGA $^{3 *}$; \\ and PAWEŁ SIENKIEWICZ ${ }^{4}$ \\ ${ }^{1}$ Department of Zoology, Marie Curie-Sklodowska University, Akademicka 19, 20-033 Lublin, Poland; \\ e-mail: arachnologia@wp.pl \\ ${ }^{2}$ Natural History Collections, Faculty of Biology, Adam Mickiewicz University in Poznań, \\ Umultowska 89, 61-614 Poznań, Poland; e-mail: pardosa@gazeta.pl \\ ${ }^{3}$ Institute of Biology, Siedlce University of Natural Sciences and Humanistics, Prusa 12, 08-110 Siedlce \\ ${ }^{4}$ Department of Entomology and Environmental Protection, Poznań University of Life Sciences, \\ Dąbrowskiego 159, 60-594 Poznań, Poland; e-mail: carabus@up.poznan.pl
}

Corresponding author: Robert Rozwałka, e-mail: arachnologia@wp.pl

(Received on 19 January 2015; Accepted on 8 December 2015)

\begin{abstract}
The paper presents data on the occurrence of Thanatus atratus in Poland. The long-lasting confusion in Polish and European literature about the existence of 2 similar species T. atratus / T. vulgaris in Poland is clarified. Diagnostic images of T. atratus reproductive organs of both sexes are presented.
\end{abstract}

Keywords: Thanatus atratus, Araneae, Poland, misidentification

\section{INTRODUCTION}

Thanatus atratus Simon, 1875 is a rare eastern Palearctic species, which due to the great morphological similarity for a long time was considered as a synonym of T. vulgaris Simon, 1870 (World Spider Catalog 2016) or as its subspecies (Kulczyński 1903; Simon 1932; TullgRen 1942, 1944; LeVy 1977; Hansen 1995). Although Kronestedt (1983) suggested that T. atratus and T. vulgaris are separate species, in a key to the spiders of Central Europe (HeImER \& NeNTwig 1991: p. 466, Fig. 1229: $\lambda, q$ ) the figure of T. vulgaris refers in fact to T. atratus. Also the descriptions of T. vulgaris in CHYZER \& KULCZYŃsKi (1891: p. 114, Pl. 4, Fig. 26: đ, , ) and Miller (1971: p. 30, Pl. XVII, Figs. 18-19: $\hat{\gamma}$, o ) refer to T. atratus. Works of Logunov (1996), Szita \& SAmu (2002), Muster \& Thaler (2003), and a recent paper of KASTRYGina \& KOVBLYUK (2013), precisely illustrate various diagnostic characters of both species. 
There is a lot of confusion around the occurrence of Thanatus atratus in Poland. The first record was published in Prószyński \& StARĘGA (1997), where W. STARĘGA listed this species on the basis of unpublished data. The species was also recorded by StaręGa et al. (2002). Blick et al. (2004) listed T. atratus, Kupryjanowicz (2008) reported on T. vulgaris, while VAn Helsdingen (2013) and Nentwig et al. (2016) listed both species from Poland. In some papers there is no evidence on where and when T. atratus or T. vulgaris was recorded in Poland (KuPRYJANOWICZ 2008, Nentwig et al. 2016). The situation of both species in the Czech Republic and in Slovakia is similar. Although BuCHAR \& RUŽIČKA (2002) clarify that all the Czech records of T. vulgaris belong to T. atratus, both species are reported from the Czech Republic in European literature (NENTWIG et al. 2016). In Slovakia, the occurrence of T. atratus was published by Kalivodová et al. (2008) and Gajdoš \& Majzlan (2010), but in older papers only T. vulgaris is mentioned, and only T. vulgaris is listed from Slovakia by Nentwig et al. (2016).

\section{MATERIAL EXAMINED}

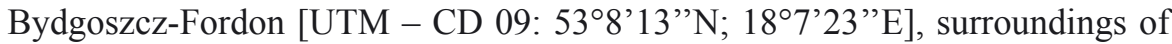
Traktorzystów Str., sandy grassland, pitfall traps, leg. et det. T. Rutkowski: 20.0702.08.2014-1웅

Gozdowice near Gryfino [UTM - VU 54: 5245'47'N; 14²0'10'”E], xerothermic grassland with Stipa sp., pitfall traps, leg. P. Sienkiewicz; det. R. Rozwałka: 15.05-4.06.2009 - 1ठ; 29.04-28.05.2010 - 1 juv.; 29.07-30.08.2010 - 1 ․

Toruń-Glinki [UTM - CD 37: 51 ${ }^{\circ} 58^{\prime} 24^{\prime}$ N; $18^{\circ} 33^{\prime 2} 28^{\prime}$ E], sandy grassland, leg. B. Łącka, det. W. Staręga: 18.07.1977 - 1ㅇ [stored in Senckenberg Museum, Frankfurt am Main].

"Ujście Warty" National Park, "Czarnowska Górka" [UTM - VU 82: $52^{\circ} 32^{\prime} 36^{\prime \prime N}$; 1445'39”'E], sandy grassland with Corynephorus canescens, sweep net, leg. et det. T. Rutkowski: 17.06.2012 - 1 ㅇ․

"Wrzosowiska Cedyńskie" Nature Reserve near Cedynia [UTM - VU 45: $52^{\circ} 51^{\prime} 20^{\prime \prime} \mathrm{N} ; 1^{\circ} 10^{\prime} 20^{\prime}$ 'E], xerothermic sandy grassland with Stipa sp., pitfall traps, leg. P. Sienkiewicz, det. R. Rozwałka: 1.08-1.09.2009 - 1 9 ; 28.05-28.06.2010 - 1ठ; 28.06-29.07.2010-4ठึ.

Total: $6 \hat{\jmath}$; 5 q + ; 1 juv.

All measurements of morphological structures given in $\mathrm{mm}$.

\section{DESCRIPTION}

Total length: ${ }^{7} 4.5-4.7$; ( 96.1$)$; carapace length: $\lesssim 2.10$ ( $\left.\$ 2.36\right)$; carapace width:

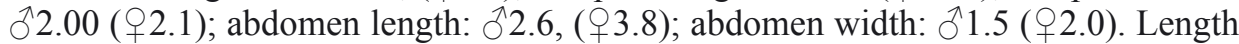
of leg segments in Tables 1 and 2, cymbium illustrated in Fig. 1b-1d, vulva in Fig. 1e. 
Body shape and coloration are similar to those of other species of the genus Thanatus C.L. Koch, 1837. Cephalothorax yellowish, with a distinct central stripe and 2 greyish lateral stripes (Fig. 1a). Clypeus with some long bristling hairs. Abdomen yellow-amber, with a dark lanceolate mark in its posterior part and a triangular or V-shaped pattern in its anterior part (Fig. 1a). Femora (and often patellae) greyishbrown in males or grey in females. Other segments orange-yellow to yellowish (pale yellow in females). The leg hairs vary from clear and fine to much thicker and darker, sometimes so thick that they can be treated as finer bristles. All tarsi and metatarsi of both male and female individuals with dense hairbrushes of scopula positioned ventrally. In anterior parts of $\mathrm{Mt}_{\mathrm{III}}$ and $\mathrm{Mt}_{\mathrm{IV}}$, hairbrush decaying. Leg hairs numerous, varied, including clear and fine hairs, and much thicker and darker ones. $\mathrm{Mt}_{\mathrm{I}}$ and $\mathrm{Mt}_{\mathrm{II}}$ with 2 pairs of ventral spines, $\mathrm{Mt}_{\mathrm{III}}$ and $\mathrm{Mt}_{\mathrm{IV}}$ with 4-6 (7) ventral or ventrolateral spines; $\mathrm{Ti}_{\mathrm{I}}$ and $\mathrm{Ti}_{\mathrm{II}}$ with 2 pairs of ventral spines. Other segments of legs with variable numbers of spines.

Table 1. Length of leg segments of male Thanatus atratus (mean for $n=3$ from "Wrzosowiska Cedyńskie" Nature Reserve)

\begin{tabular}{lcccccc}
\hline & Femur & Patella & Tibia & Metatarsus & Tarsus & Total \\
\hline Leg I & 2.10 & 0.88 & 1.74 & 1.26 & 0.90 & 6.9 \\
Leg II & 2.20 & 0.92 & 1.90 & 1.50 & 0.88 & 7.4 \\
Leg III & 1.80 & 0.72 & 1.76 & 1.30 & 1.00 & 6.6 \\
Leg IV & 2.20 & 0.80 & 2.00 & 1.70 & 1.06 & 7.8 \\
\hline
\end{tabular}

Table 2. Length of leg segments of female Thanatus atratus ( $n=1$ from Gozdowice)

\begin{tabular}{lcccccc}
\hline & Femur & Patella & Tibia & Metatarsus & Tarsus & Total \\
\hline Leg I & 1.80 & 0.86 & 1.60 & 1.20 & 1.00 & 6.5 \\
Leg II & 2.10 & 0.84 & 1.80 & 1.40 & 0.96 & 7.1 \\
Leg III & 1.90 & 0.70 & 1.50 & 1.32 & 0.86 & 6.3 \\
Leg IV & 2.20 & 0.84 & 1.84 & 1.68 & 0.96 & 7.5 \\
\hline
\end{tabular}

\section{DISCUSSION}

The verified new records presented here clearly confirm the occurrence of Thanatus atratus in Poland. This is a rare spider species, probably occurring only locally, in a few isolated localities. We investigated several dozen various xerothermic sites in 


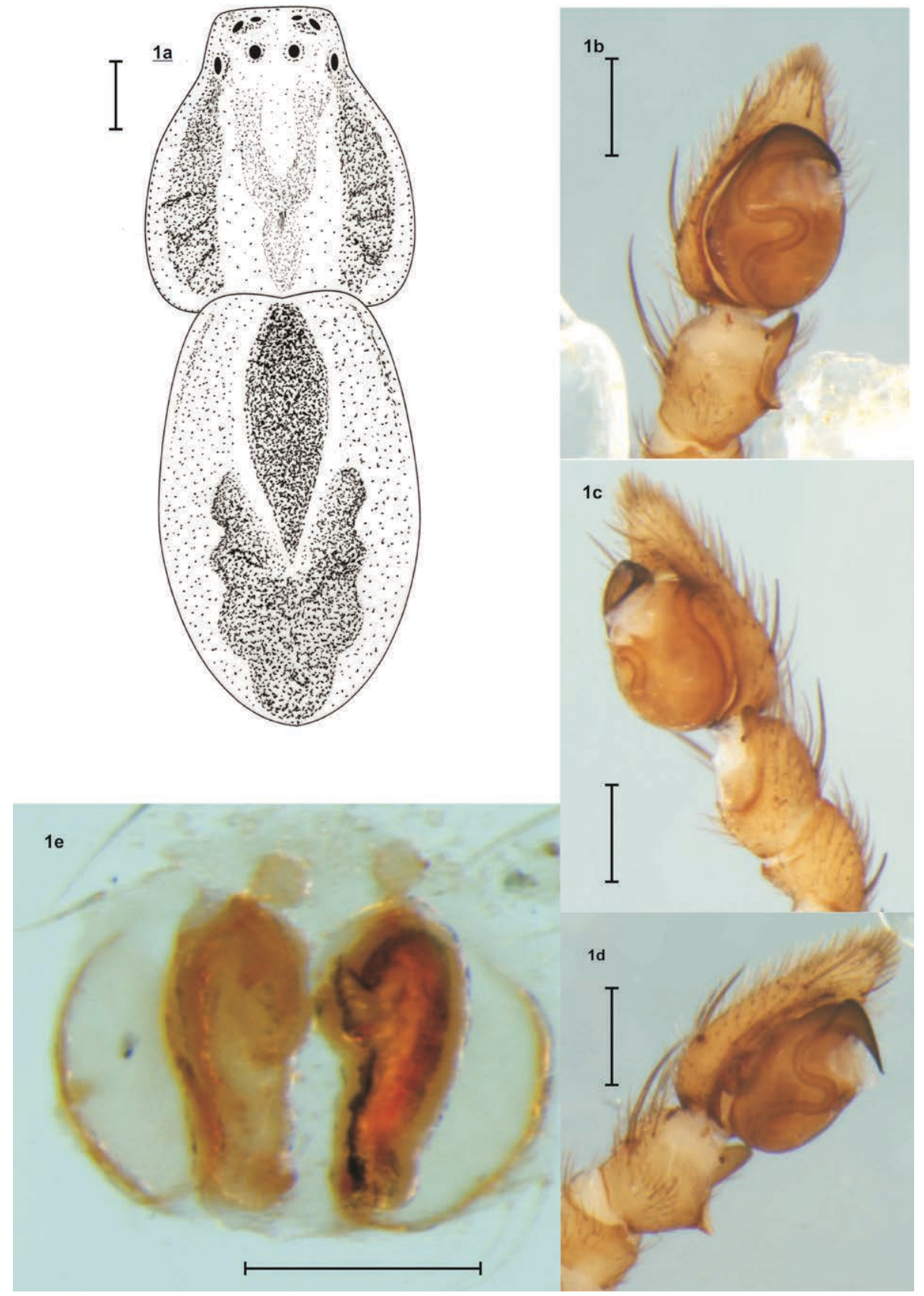

Fig. 1. Thanatus atratus: $1 \mathrm{a}-$ male habitus; $1 \mathrm{~b}-$ male palp, frontal view; $1 \mathrm{c}-$ male palp, retrolateral view; 1d - male palp prolateral view; 1e - vulva. Specimens from Gozdowice. Scale bars: $1 \mathrm{a}-0.5 \mathrm{~mm} ; 1 \mathrm{~b}-\mathrm{e}-0.25 \mathrm{~mm}$. 


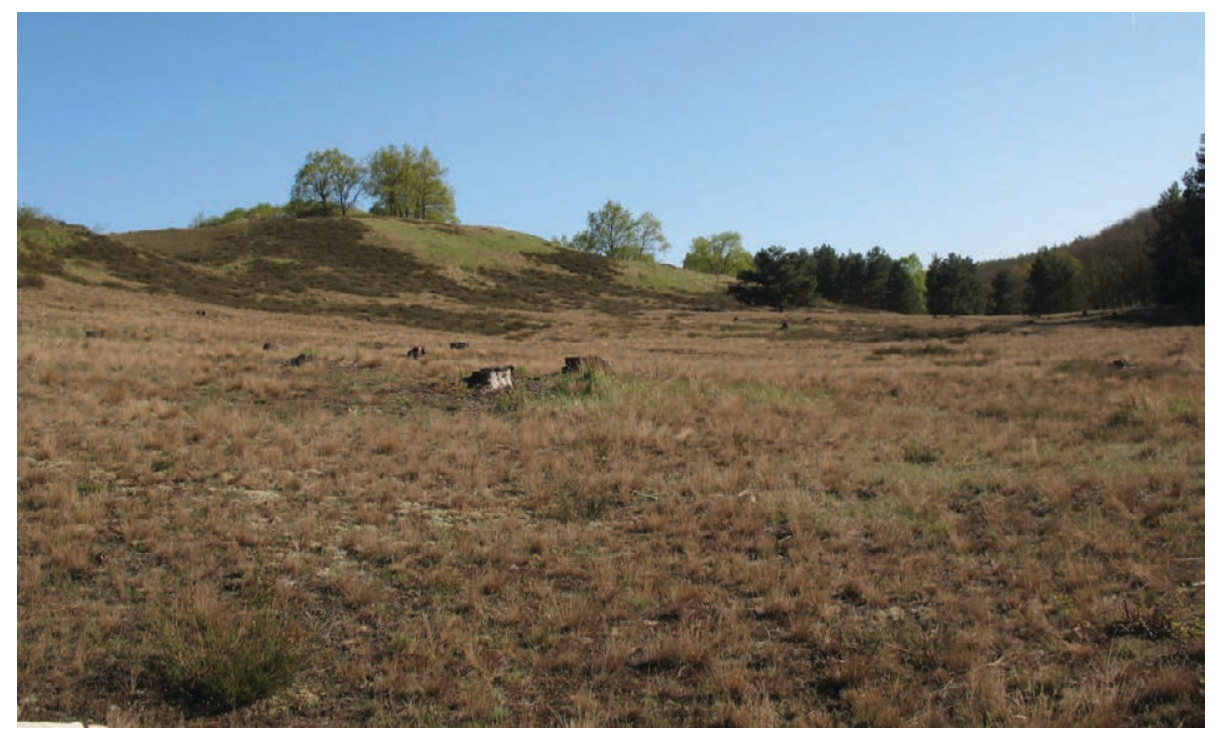

Fig. 2. Habitat of Thanatus atratus in "Wrzosowiska Cedyńskie" Nature Reserve (Photo: P. Sienkiewicz)

2009-2014 (unpubl. data) and recorded T. atratus only in 4 of them. During the same period and in the same localities, we recorded a lot of individuals of $T$. arenarius, T. formicinus and T. sabulosus. The distribution of T. atratus in Poland suggests that this species is found mainly within the Thorn-Eberswalde Proglacial Valley (Fig. 3). It prefers warm, open habitats with a sandy substrate (BRANDT 2005; ALMQUIST 2006; Brandt 2010; Nentwig et al. 2016) (Fig. 2). Several localities of this species were found west of the Oder and the Lusatian Neisse (STAUDT 2016), so it seems possible to record T. atratus in southwestern Poland in the future (Fig. 3).

The chronology of records of T. atratus in Germany, the Czech Republic, and Slovakia suggests that this species extends its range of distribution to the north and east, and most of its localities were reported during the last 25 years (GAJDOš et al. 1999; BuCHAR \& RŮŽIČKA 2002; STAUdT 2016). However, this hypothesis is not necessarily correct. The increase in the number of localities of T. atratus in recent years may also be a result of more research in xerothermic grasslands - the habitats in which this rare species occurs. In Poland it is known since the 1970s, and new information complements the data on its distribution.

On the basis of the analysis of the used synonyms, we conclude that all the published records of Thanatus vulgaris in Poland (KuPRYJANOWICZ 2008; RozwaŁKA \& Stańska 2008; van Helsdingen 2013; Nentwig et al. 2016) are mistakes. 


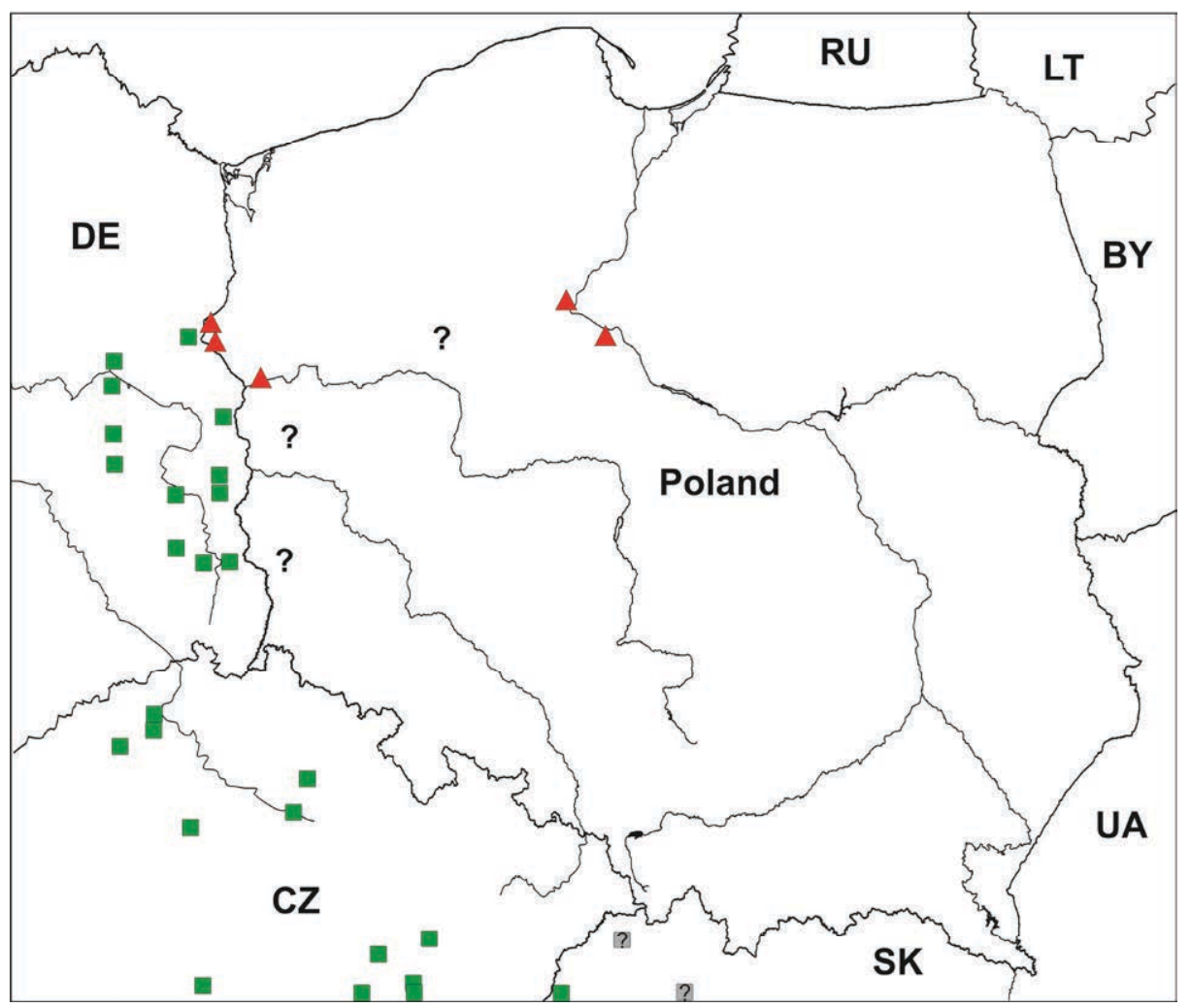

Fig. 3. Distribution of Thanatus atratus in Poland and neighboring countries: red triangles $=$ localities in Poland; green squares = localities in Germany, Czech Republic and Slovakia; grey squares with "?" = alleged localities of $T$. vulgaris, probably related to misidentified T. atratus; ? = presumable occurrence.

\section{REFERENCES}

AlmQuist S. 2006. Swedish Araneae, part 2 - families Dictynidae to Salticidae. Ent. Scand., Suppl. 63: 287-603.

Blick T., Bosmans R., Buchar J., Gajdoš P., Hänggi A., van Helsdingen P., Ružicka V., Staręga W., Thaler K. 2004. Checkliste der Spinnen Mitteleuropas [Checklist of the spiders of Central Europe. (Arachnida: Araneae)]. Version 1.; online at http://www.arages.de/checklist. html\#2004_Araneae

BRANDT D. 2005. Beitrag zur Arthropodenfauna der Oderhänge und der Oderaue von Lebus - Faunenanalyse und Bewertung (Coleoptera, Heteroptera, Hymenoptera, Saltatoria, Araneae, Opiliones u. a.). Märkische Ent. Nachr. 7: 1-52.

BRANDT D. 2010. Beitrag zur Arthropodenfauna des Naturparks Dahme-Heideseen (Land Brandenburg) - Faunenanalyse und Bewertung - (Coleoptera, Auchenorrhyncha, Heteroptera, Hymenoptera part., Saltatoria, Diptera part., Araneae, Opiliones, Chilopoda, Diplopoda u.a.). Märkische Ent. Nachr. 12: 195-298. 
Buchar J., RưŽIČKa V. 2002. Catalogue of spiders of the Czech Republic. Peres, Praha, 351 pp.

Chyzer C., Kulczyński W. 1891. Araneae Hungariae. Budapest, I: 1-170, pl. 1-6 (in Latin).

Gajdoš P., MaJzlan O. 2010. Pavúky (Araneae) pieskov v okolí Malaciek a Lakšárskej Novej Vsi. Naturae tutela, 14: 173-182 (in Czech).

Gajdoš P., Svatoň J., Sloboda K. 1999. Catalogue of Slovakian spiders. Bratislava, 337 pp.

HANSEN H. 1995. Über die Arachniden-fauna von urbanen Lebensräumen in Venedig - III. Die epigäischen Spinnen eines Stadtparkes (Arachnida: Araneae). Boll. Mus. civ. Stor. nat. Venezia, 44: 7-36 (in German).

Heimer S., Nentwig W. 1991. Spinnen Mitteleuropas. Ein Bestimmungsbuch. Parey, Hamburg, 554 pp (in German).

Kalivodová E., Kubíček F., Bedrna, Z., Kalivoda H., Gavlas V., Kollár J., Gajdoš P., Štefanovičová O., Wiesbauer H. 2002. Viate piesky Slovenska [Sand dunes of Slovakia]. Luka-Press, Bratislava, 60 pp (in Czech).

Kastrygina Z.A., Kovblyuk M.M. 2013. A review of the spider genus Thanatus C.L. Koch, 1837 in Crimea (Aranei: Philodromidae). Arthropoda Selecta, 22: 239-254.

KRonestedt T. 1983. Spindlar på Ölands Stora alvar. Ent. Tidskr. 104: 183-212 (in Swedish).

KULCZYŃSKI W. 1903. Aranearum et Opilionum species in insula Creta a comite Dre Carolo Attems collectae. Bull. Inter. Acad. Sci. Cracovie, Kraków, 32-58 (in Latin).

Kupryjanowicz J. 2008. Pająki (Araneae). [In:] Bohdanowicz W., Chudzicka E., Pilipiuk I. \& SkiBIŃSKA E. [Eds.], Fauna Polski - charakterystyka i wykaz gatunków. Muzeum i Instytut Zoologii PAN, Warszawa, pp. 223-255 (in Polish).

Levy G. 1977. The philodromid spiders of Israel (Araneae: Philodromidae). Israel Jour. Zool. 26: $193-229$.

Logunov D.V. 1996. A critical review of the spider genera Apollophanes O.P.-CAmBridge, 1898 and Thanatus C.L. KocH, 1837 in North Asia (Araneae, Philodromidae). Rev Arachnol. 11: 133-202.

Miller F. 1971. Pavouci-Araneida. Klíč zviŕřeny CSSR, Praha, 4: 51-306 (in Czech).

Muster C., Thaler K. 2003. The Thanatus striatus species group in the eastern Alps, with description of Thanatus firmetorum sp.n. (Araneae: Philodromidae). Bull. Br. Arachnol. Soc. 12: 376-382.

Nentwig W., Blick T., Gloor D., Hänggi A., Kropf C. 2016. Spinnen Europas, online at www. araneae.unibe.ch, accessed on January 2016.

PrószyŃSKi J., StaręGa W. 1997. Araneae. [In:] Razowski J. [Ed.], Wykaz zwierząt Polski. Instytut Systematyki i Ewolucji Zwierząt PAN, Kraków, 4: 175-189 (in Polish).

Rozwatka R., Stańska M. 2008. Lista gatunków pająków (Araneae) Polski, online at http://www. arachnologia.edu.pl/gatunki/7-pajaki-polski.html (in Polish).

Simon E. 1932. Les arachnides de France. Tome VI. Synopsis générale et catalogue des espèces françaises de l'ordre des Araneae; 4e partie. Paris, 6: 773-978 (in French).

Staręga W., BŁaszak Cz., Rafalski J. 2002. Arachnida Pajęczaki. [In:] GŁowaciński Z. (Ed.), Czerwona lista zwierząt ginacych i zagrożonych w Polsce. Kraków (IOP PAN), pp. 133-140 (in Polish).

STAudt A. 2016. Nachweiskarten der Spinnentiere Deutschlands (Arachnida: Araneae, Opiliones, Pseudoscorpiones), online at http://www.spiderling.de/arages/, accessed on January 2016.

Szita É., SAmu F. 2000. Taxonomical review of Thanatus species (Philodromidae, Araneae) of Hungary. Acta Zool. Hung. 46: 155-179.

Tullgren A. 1942. Bidrag till kännedomen om den svenska spindelfaunan. I. Ent. Tidskr., 63: 217-234.

Tullgren A. 1944. Svensk Spindelfauna. 3. Araneae (Salticidae, Thomisidae, Philodromidae och Eusparassidae). Stockholm, 108 pp.

van Helsdingen P. 2013. Fauna Europaea: Araneae: Fauna Europaea, version 2.6, online http:// www.fauna-eu.org, accessed on February 2016.

World Sider Catalog 2016. World Spider Catalog. Natural History Museum Bern, online at http://wsc.nmbe.ch, version 17.0, accessed on January 2016 (in German). 